\title{
A Pragmalinguistic - Assessment of Three Translations of the Meaning of the Qur'anic Reprehensible Moral Traits into English
}

\author{
Ali Albashir Mohammed Alhaj Majda Babiker Ahmed \\ Dina Ali Abdalla Ali Samar YanAllah Alnmer Algahtani \\ King Khalid University
}

\begin{abstract}
The current study reports the results of a research that aimed markedly at probing the loss in rendering the meaning of the Qur'anic reprehensible moral traits into English, and how these a pragmalinguistic losses can be decreased minimally The study also aimed at identifying the causes of the intended pragmalinguistic losses. Three ayahs were purposefully selected to address the questions of the study. The results revealed that the pragmalinguistic loss in rendering the meaning of Qur'anic reprehensible moral traits into English occurred attribute to spectra of factors such as lack of equivalence and the translation strategies adopted by the three translators who respectively are" Abdullah Yusuf Ali (The Meanings of the Glorious Quran), Muhammad Mahmoud Ghali.( Towards Understanding the Ever Glorious Quran) ,Mohammed Asad( The Message of the Quran). Last not the least the study suggests solutions for the identified problems.
\end{abstract}

Keywords: reprehensible moral traits, translation strategies translation loss, the Holy Quran,.

DOI: $10.7176 / \mathrm{JLLL} / 65-02$

Publication date: February $29^{\text {th }} 2020$

\section{INTRODUCTION}

At the outset, the translators of the Holy Quran encounter challenging task in translating the Holy Quran discourse in particular due to the dearth of many reasons .The first one is that: the Holy Quran has its own independent genre .And such uniqueness can never be imitated. According to Al-Baqillani, a moslem theologian and scholar (950-1013)"No human literary criteria could be used or applied to evaluate it... it is the nature of the speaker himself, God, that makes it impossible to speak of any kind of similarity or comparability between the Quran and any other text." (As cited in Abu Zayd 2003,p.3)(Retrieved on 22/11/2019 from https://www.iasj.net/iasj?func=fulltext\&aId=1938).,

Indeed this challenging task has been taken so lightly. According to Akbar (1988, p.89):

The language of the Holy is by turn is striking, soaring, vivid, terrible, tender and breathtaking.....

On his turn (Abdul-Raof, 2005) points out:

The Qur'anic discourse has its own distinctive features at the syntactic, cultural (stylistic) and rhetorical level- the italics is ours) (p.17)

On this context, we can quote, Tabrizi \& Mahmud (2013)

These features of the Qur'anic text together yield the supreme vividness, which is challenging for a translator. Moreover, translating the Holy Quran text is challenged by many obscurities, ambiguities and nonequivalence problems (pp.1-6)

The second reason is that: the equivalence of the original text is virtually impossible : hence the absolute untranslatability of a text has become a linguistic axiom . Tibawi(1964/2004) is of the opinion that" every translation of the Holy Quran proclaims its own inadequacy".. So translation of the Holy Quran into mundane language has multifarious linguistic problems. No doubt the translators are trying their best through all possible means to translate the Message if the Holy Quran, but usually, they succeed in interpreting any one shade of the meaning of a word out of a spectrum of it colours.( Khan, 2008,p.1). As Abdelaal( 2019,p.13)opines:

Although great efforts have been shown by some translators to produce reliable translation into English, the quality of those translations is poor; the translated texts are either inaccurate or biased; and thus, most of the existing translations of the Holy Quran suffer from serious shortcomings and limitations, which either distort the meanings of the sacred text of the Holy Quran, or make it incomprehensible. Retrieved on $22 / 11 / 2019$ http://www.pertanika.upm.edu.my/Pertanika\%20PAPERS/JSSH $\% 20$ Vol.\%2027\%20(1)\%20Mar.\%202 019/02\%20JSSH-2438-2017.pdf

The Holy Qur'an is rich in the euphemistic expressions dealing with sensitive topics such as arrogance , greediness, death ...etc that need to be translated and examined. Sacredness and beauty of the Holy Qur'an makes translation of the Qura'nic euphemisms problematic and challenging. In order to convey the accurate and miraculous Islamic values, the translator is forced to use different strategies such paraphrase, partial equivalents, literal translation, functional translation, addition, ...etc, also assumed that due to the shortcomings in the translated text it cannot attain the overall semantic value as well to achieve the pragmatic impact that the original text enjoys. 
The current paper aims at investigating problems and constrains of rendering some reprehensible moral traits in three English translations of the Holy Quran

\section{A. Objectives of the Study}

The study aims at:

a. at identifying the losses in rendering the reprehensible moral traits in the translation of the Holy Quran, and how these losses can be reduced, and the causes of the difficulty in conveying some euphemistic meanings in the translation of the Holy Quran.

b. investigating the strategies used by Abdullah Yusuf Ali, Muhammad Mahmoud Ghali and in rendering reprehensible moral traits in some selected ayahs of the Holy Qur'an..

\section{B. Questions of the Study}

To meet the stated objectives, the following research questions were raised:

1. To what extent do losses in rendering the meaning of the Quranic reprehensible moral traits occur i?

2. How can the identified losses be reduced?

3. What are the causes of the difficulty in conveying the Quranic reprehensible moral traits into English ?

\section{LITERATURE REVIEW}

The concept of Euphemism in English and Arabic language

Sociolinguists classified euphemism into many categories according to different rules and principles. For instance, Rawson (1981) divided euphemisms into two general types; positive and negative euphemism. According to Rawson (1981), positive euphemisms existed for the sake of politeness and to achieve cooperation among the members of a specific society, in a specific situation, within a specific culture. For example, for the sake of respect, in English language, the word garbage man is substituted by the euphemism "environmental beautician" and hospital nurse is euphemized as "angel in white" and "low-income" instead of poverty as well as behind the bars (in jail), intoxicated instead of drunken, overweighed instead of fat etc....Also The euphemisms for the word dying in English include: to pass away, one's last breath, going to a better place, with the angels, join the majority, depart, meet his/her maker, feeling no pain, cross the bridge, resting in peace, go west, kick the bucket, bite the dust etc

Rawson (1981) argued that the negative euphemisms conceal the reality and are used for the sake of deception. For instance, Adams (1985) offered this example, "President Reagan, trying to obscure the fact that the MX missile is an awesomely destructive weapon, tried to title it 'The Peacekeeper' (p.45).

Lutz (1989) provided this definition of negative euphemism:

misleads, distorts, reality, pretends to communicate makes the bad seem good, avoids or shifts responsibility, makes the negative appear positive, creates a false verbal map of the world, limits, conceals, corrupts, prevents thought, makes the unpleasant appear attractive or tolerable and creates incongruity between reality and what is said or not said (p.62).

Euphemisms, whether positive or negative, can be divided into unconscious euphemisms and conscious euphemisms. The criterion is the euphemistic meaning whether correlative with the original meaning or not. Unconscious euphemisms, as its name implies, were developed long ago, and are used unconsciously, without any intent to deceive or evade. For example, "Indisposition" has been a substitute for "disease" for a long period; people seldom realize that its original meaning is incapable of dealing with something. Or "Dieter", the original meaning "taking food by a rule or regulation" has been substituted by the euphemistic meaning "the one moderate in eating and dining for losing weight". From the above we can conclude that unconscious euphemisms were developed so long ago that few can remember their original motivations. 31 Conscious euphemisms are widely employed, which involve more complex categories. When people communicate with each other, speakers are conscious to say tactfully, and the listeners understand their implied meanings. For example, when a lady stands up and says that she wants to "powder her nose" or "make a phone call" at a dinner party, the people present realize the euphemism means "something else", that is, "going to the ladies" room".

On the other hand, Leech (1998) stated that :

"there is a particular kind of euphemism that involves using language in a perverse way to conceal thought. This is called DOUBLESPEAK” (p.192).

Doublespeak is language that pretends to communicate but really does not; it is language that makes the bad seem good, the negative appear positive, the unpleasant appear attractive or at least tolerable. Doublespeak is language that avoids responsibility, language that is at variance with its real or purported meaning. It is language that conceals or prevents thought. Rather than extending thought, doublespeak limits it... "(Lewis, 2005,p.16). According to them, doublespeak is classified into four categories:

1. The first is the euphemism which is an inoffensive or positive word or phrase used to avoid a harsh, unpleasant or distasteful reality. 
2. The second is jargon which is the specialized language of a trade, profession, or similar group, such as that used by doctors, lawyers, engineers, educators or car mechanics.

3. The third is gobbledygook or bureaucratese: Basically, such doublespeak is simply a matter of piling on words, of overwhelming the audience with words; the bigger the words and the longer the sentences, the better.(Laboner,.2008,p.3)

4. The fourth kind is inflated language that is designed to make the ordinary seem extraordinary, to make everyday things seem impressive, to give an air of importance to people, situations or things that would not normally be considered important and to make the simple seem complex. What distinguishes doublespeak from other euphemism is its deliberate usage by governmental, military or corporate institution. Doublespeak is, in turn, distinguished from jargon in that doublespeak attempts to confuse and conceal the truth and jargon often provides greater precision to those that understand it (while inadvertently confusing these who don't). An example of the distinction is the use by the military of the word 'causalities' instead of 'deaths'-which may appear to be an attempt to hide the fact that people have been killed. It is actually a precise way of saying "personal who have been rendered incapable of fighting, whether by being killed, being badly injured, psychologically damaged, incapacitated by disease, rendered ineffective by having essential equipment destroyed, or disabled in any other way". "Causalities" is used instead of 'death', not for propagandistic or squeamish reasons, but because most causalities are not dead, but nevertheless useless for waging war. Proper example of doublespeak included taking friendly fire as a euphemism for 'being attacked'. Commentators such as Noam Chomsky and George Orwell have written at length about the dangers of allowing such euphemism to shape public perception and national policy(Lysons,.1998,p.6)

The concept of euphemism in Arabic has undergone a long process of discussion started with the efforts exerted by early Arab linguists until the modern Arab linguists who were influenced by the Western linguists.

Early Arab linguists

Arab linguists refer to euphemism as two rhetorical devices known as kinayah كناية and Tarid التعريض ( metonymy and innuendo).According to Khalifa,2005,p.165):

a number of Arab of Scholars of Arabic rhetorics have touched upon the concept of euphemism in Arabic giving it a number of labels lutf al-ta'bir التنطف في التعبير al-talatf fi al-ta'bir , لطف التعبير , and tahsin al-lafz تحسين اللفظ

(Metonymyالكناية) , as Arab literature on rhetoric states, was the first device used to throw light on euphemism, and under which aspects of euphemism were explained, Al-Farra' (1970,p. 316) was the first linguist who referred to euphemism and taboo when he illustrated verses from the Qur'an. He discussed serious issues like copulation, euphemism for woman; of which was الفراش (the bed), and other issues that paved the way to deal with sensitive matters in language. Al-Jahidh (1998,p.257) metonymized some taboo topics like sex, prostitution, and old age. His reference to these topics indicates the fact that direct reference to socially unaccepted matters is not preferable. This book was written in the second century after Hijrah. Ibn Quteibah (1986,p.214) used the terms حسن التعريض (euphemism) and (beauty of innuendoes) since both these terms indicate euphemism. Al-Mubarid (1986,p.855) followed the same steps of those who preceded him. He discussed euphemism also under metonymy as Arabs avoid mentioning rejected expressions directly. . (Khalifa,2005)

In his masterpiece of the 4th century after Hijrah, Ibn Faris (1910/1999,p.218) did the same when referring to metonymy. Arabs euphemize unspeakable things in their speech such as genitals, defecation, and some other taboo issues. Al-Easkari (1952/1995,p427) used المحسن اللفظي (verbal beautification) to label euphemism, while Ath-ThaEalibi (1998) devoted a book on metonymy and innuendo. This book dealt with all areas of taboo and how they are euphemized to make them mentionable. In addition to his use of metonymy, Ibn Rashiq (1972,p.311) believed that التورية (equivocation) is a device through which unmentionable matters are expressed. Like AthThaEalibi in dealing with euphemism, Al-Jirjani (1908/1991) wrote a book on metonymy and references. He did the same to cover as many taboo matters as possible that can be expressed via metonymy and reference. Both of them (Ath-ThaEalibi and Al-Jirjani) left authoritative rules and authentic literature on metonymy in Arabic. In the seventh century after Hijrah, Ibn Al-Atheer (1983,p.51), Ibn Abi Al-EsbeE (1980,p.53), and AlQurtubi (2003,p.317) used metonymy to discuss euphemism. Ibn-Atheer and Ibn Abi Al-EsbeE defined and clarified metonymy; these definitions and classifications indicate the importance of euphemism in language. In the eighth century, unlike Al-Ealawi (1922,p81) and Az-Zarkashi (1984) who followed their predecessors in employing metonymy for referring to euphemism, At-Tibi (1977) uses the term الرمز (symbol) to state euphemism as it refers to intended matter indirectly. (Ibid,2013)

Modern Arab linguists have tried to give certain terms for euphemism in Arabic. These efforts have been reflected in their writings on euphemism. At-Tarabulsi (1981,p.213) discusses euphemism under التطيف (softening) as a matter of translating the term euphemism from English into Arabic. Xarma (1978,p.176) calls them mild and polite expressions which can be used to avoid taboo sanctions imposed by the society. Al-Khuli (1982,p.282) translates the English word euphemism into Arabic as تلطيف العبارة (softening the expression) or التورية (equivocation). LeEebi (1984,p.105) refers to euphemism by using the term حسن التعبير (beauty of 
expression) or الكناية (metonymy). While Ayoub and Aziz (1998,p.125) translate the term of euphemism into التهوين (comfort). Ali(1983,p.64) uses نحسين اللفظ (beautification of expression) next to the English word euphemism when he discusses this subject. Ad Dayah (1996,p.395) follows the term assigned to euphemism by early linguists so that الكناية (metonymy) is employed here. Eawad and Eakrimah (2006,p.8) explain the semantic function in language-they refer to euphemism as التلطف), it is used to avoid taboo matters which are sources of changes in language. Both Ath-Thubeiti (2001,p.961) and Abu- Xuder (2010,p.5) adopt the same term التلطف, whereas Eumer (1998,p.228) translates the terms التلطف في التعبير anto English as euphemism.

Arab linguists paid attention to the role of context in using language. The contextual factors represented by the relation between participants in a given situation and formality are the cornerstone in the process. Thus, Farghal (1995,p.367) describes that euphemisms are pragmatic choices by users of language to fulfill interaction; this choice "is not arbitrary, rather, it is intentional undertaking opted for in light of diversified contextual factors that include knowledge of social role or status, spatial and temporal location, formality level, the medium, subject matter ...".

The Concept of Translation"

Translation as a term might be a new word for a very ancient concept, meaning 'transfer'. the common use of this term is as Steiner once said, 'the transfer of meaning between languages' (1998, p 287). Although thisterm previously had been used to mean the physicalremoval from one spot to another as Susan points out, 'To translate is still to lead something across a gap, to make something go where it was not' (Sontag 2001, p 340).Freeman argues that translation "consists largely in statements and reflections on their craft by practitioners, and their ideas vary according to what is being translated, whether the Bible, poetry, literary prose or a legal document. It is often as much ideology as theory but remains important in its insistence that translation is anything but simple and mechanical'(Freeman 2009, p 442). However, Freeman also said the 'translators' concerns have changed little over centuries of practice and he wondered how literal should translation be? Should it be word-for-word, or should it seek to uncover and reproduce the intention of an author and the effect on a reader in some other way? Should a translation conform to the structure and vocabulary of the target language, 'domesticating' the foreign text, or should it retain a sense of foreignness, enriching the target language with new resources? Should translation use estrangement of this kind to draw attention to itself, to its status as a text which has been translated? To what extent is the translator secondary or subservient to an original author, and to what extent is he himself or she herself the author of a new text?" on the other hand Bhatia define it as " thecommunication of the meaning of a source-language text by means of an equivalent target-language text" (Bhatia1992, p 1051).Callon suggests that to translate is 'to express in one's own language what others say and want, why they act in the way they do and how they associate with each other: it is to establish oneself as a spokesman' (Callon 1986, p 223). And since then translation has been viewed differently.

Temple has argued, translation demands explicit methodological attention. We should treat it as a problem of representation, with all the political and ethical questions thatentails. Translation decisions should be revealed for what they are, by making them open, explicit and subject to debate (Temple , 2005).Mundray illustrates in the concept of this term saying that In the field of languages, it simply has severalmeanings:(1) the general subject field or phenomenon ('I studied translation at university')(2) the product - that is, the text that has been translated ('they published theArabic translation of the report')(3) the process of producing the translation, otherwise known as translating('translation service'). Theprocess of translationbetween two different written languages involvesthe changing of an original written text (the source text orST) in the originalverbal language (thesource language orSL) into a written text (thetarget textorTT) in a different verbal language" (Jeremy 2006, p 5).According to Nida and Taber in The Theory and Practice of Translation, "Translating consists in reproducing in the receptor language the closest natural equivalent of the source-language message, first in terms of meaning and secondly in terms of style". Nida also states that translation consist of reproducing in the receptor language the closest natural equivalence of the source language message, first in terms of meaning and secondly in terms of style.According to Ghazala (1995), "translation is generally used to refer to all the process and methods used to convey the meaning of the source language in to the target language' P.1. Ghazala's definition focuses on the notion of meaning as an essential element in translation. That is, when translating, understanding the meaning of source text is vital to have the appropriate equivalent in the target text thus, it is meaning that is translated in relation to grammar, style and sounds (Ghazala, 1995). On the contrary, " Translation is a process and a product. According to Catford (1995). Jakobson classified translations into three possible types: intralingual, interlingual, and intersemiotic. The Interlingual Translation, or proper translation, is defined as "an interpretation of verbal signs by means of some other language" Newmark defines the act of translating as transferring the meaning of a text, from one language to another, taking care mainly of the functional relevant meaning, it is the rendering of the meaning of a text into another language in the same way that the writer intended the text.Dryden defines three types of translation: Metaphrase, which is literal and word for word; Paraphrase, which captures the general sense or meaning; and Imitation, which is a more liberal adaptation. He calls the first and last extremes and claims that the middle way is the way to go. Umberto Eco argues that the translation is not about comparing 
two languages, but about the interpretation of a text in two different languages, thus involving a shift between cultures. He said translating means making the text understandable to a different language reader.

\section{METHODS}

\section{The Study Design}

,In this study the researchers used the analytical descriptive qualitative method, due to the complex nature of the examined text (i.e. The Holy Quran). As suggested by Creswell (2007), qualitative research is conducted when researchers seek understanding of a complex issue, and when quantitative measurements and analyses do not seem appropriate for the research problem under investigation.

The study aims at seeking the problems and constrains of rendering some reprehensible moral traits in three English translations of the Holy Quran Furthermore, the researcher analyzed the Arabic reprehensible moral traits and compared and assessing them to the three different translations of the Holy Qur'an of Abdullah Yusuf Ali (The Meanings of the Glorious Quran), Muhammad Mahmoud Ghali.( Towards Understanding the Ever Glorious Quran) ,Mohammed Asad( The Message of the Quran). Finally, the researchers analyzed and compared different approaches to translating euphemisms in the Holy Qur'an into English.

\section{Sampling}

The current research aims at describing, analyzing and evaluating the principles, methods and procedures of translating the reprehensible moral traits meanings of the Holy Quran, and particularly, explaining the problems of translating the euphemism in three translations of the meaning of the Holy Qur'an .

Purposive sampling was adopted for this study, as it is deemed appropriate for the analytical descriptive qualitative method, such as this study. Three examples were purposefully extracted from ,Surrat Al-Isara, Lugman, and At-Tawbah). In this regard, the researcher carefully selected the samples that show semantic losses in the Qur'anic reprehensible moral traits meaning occur in the translation of the Holy Quran. The translations selected are Abdullah Yusuf Ali's translation and Muhammad Mahmoud Ghali's translation and Mohammed Asad's translation. These three translations were selected because they belong to two different far-between periods of translation, which can explain clearly the differences among translations of the Holy Quran throughout a long period of time. In addition, the methodology adopted in the three selected translations is quite poles apart. Ali's translation is elaborative which mostly tends to employ paraphrase and transliteration as translation strategies. However, Ghali's translation tends to be brief and avoids paraphrasing and transliteration Asad's translation tends to be translationese ( strictly formal) (Khan, 2008,p.165). Thus, selecting these three translations is to identify the extent the employment of certain translation strategies succeeds in conveying the Qur'anic reprehensible moral traits meaning into English

\section{Data Analysis}

The Researcher analyses the data by using comparative analysis, as well as by reading the original texts of Qur'anic reprehensible moral traits in Arabic and compares them to their English translation version. Then, looking up a reliable and specialized dictionary and books of Tafaseer and applying the researcher skills of translation to find out whether the dictions and meanings of translated versions of reprehensible moral traits are accurate or not.

The data of this research consist of ayhas(verses) of the Holy Qur'an in Arabic containing reprehensible moral traits .

\section{Procedures}

The most vital and crucial research instrument is reading, analyzing and comparing the translated text of selected Surrah by the three different translators. This study is an eclectic, three translations of the meaning of the Holy Qur'an have been analyzed and identified as the different kinds of translation, i.e. semantic translation, communicative translation etc. When analyzing the three translations, the researchers followed the following procedures:

(i) the researchers obtained the three translations of the meaning of Holy Quran, entitled Abdullah Yusuf Ali (The Meanings of the Glorious Quran), Muhammad Mahmoud Ghali.( Towards Understanding the Ever Glorious Quran) ,Mohammed Asad( The Message of the Quran).

(ii)quoting the Arabic versions of Quranic ayat in which euphemism under investigation occur, enumerating reprehensible moral traits lexemes in both versions Arabic and English ,and then putting the three translations of the same ayah into a table directly under each one of the three translators.

(i) studying each reprehensible moral traits lexemes in terms of the problems of meaning and textual problems based on (high/average/low) semantic and communicative methods of translation.

(ii) studying each reprehensible moral traits lexeme in terms of the problems of meaning and textual problems based on (strong/mid/weak) connotation.

(iii) analyzing reprehensible moral traits aspects of meaning focusing on some selected ayahs in which euphemism appears in the Holy Qur'an, here the researcher chooses some examples for the context particularly in which euphemism appears. 
(iv) analyzing Abdullah Yusuf Ali, Muhammad Mahmoud Ghali) ,Mohammed Asad'stranslations and identifying their accuracy, effectiveness, and then giving comments on the three translations.

\section{Research Instrument}

Research instrument is very important to obtain the result of a study, it is a set of methods which are used to collect the data. The researchers act the instrument of the study. Cresswell (1994,p.145) states that the qualitative research is the primary instrument for the data collection and data analysis. Besides that, the researchers spend a great deal of time in reading, reciting, exploring and comparing the dictions and meanings of Qur'anic reprehensible moral traits .. Then the data will be analyzed by the researchers in accordance with the problem of the study.

\section{Examples of Reprehensible Moral Traits (Arrogance)in The Holy Quran Translation}

Example 1

1 1

wa laa tamshi fil ardi maarahan

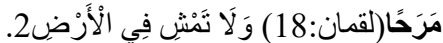

The triliteral root mim rā ḥa $(ح, \rho)$ occurs three times in the Quran, in two derived forms:

- $\quad$ once as the form I verb tamrahu $\left(\mathcal{C}^{2} \mathcal{z}\right)$

- $\quad$ twice as the noun marah (مَ)

- Retrieved on 30/11/2020 http://corpus.quran.com/qurandictionary.jsp?q=qbD

\begin{tabular}{|c|c|c|c|}
\hline $\begin{array}{c}\text { ST } \\
\text { ( euphemism, } \\
\text { arrogance ) }\end{array}$ & $\begin{array}{c}\text { T1 } \\
\text { AbdullahYusuf Ali, }\end{array}$ & 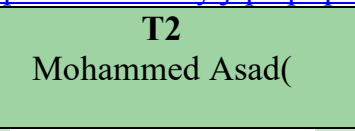 & $\begin{array}{c}\text { T3 } \\
\text { Muhammad Mahmoud } \\
\text { Ghali. }\end{array}$ \\
\hline 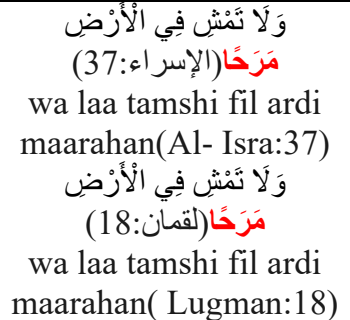 & $\begin{array}{l}\text {-Nor walk on the earth } \\
\text { with insolence ( Al- } \\
\text { Isara:37) } \\
\text {-Nor walk in insolence } \\
\text { through the } \\
\text { earth .( Lugman:18) }\end{array}$ & $\begin{array}{l}\text {-And walk not on the } \\
\text { earth with haughty } \\
\text { "( Isara:37) } \\
\text {-And walk not on the } \\
\text { earth with self } \\
\text { concept.( Lugman:18 }\end{array}$ & $\begin{array}{l}\text {-And do not walk in the } \\
\text { earth merrily("(Al- } \\
\text { Isara: } 37 \text {. } \\
\text {-And do not walk in the } \\
\text { earth merrily(Lugman:18 }\end{array}$ \\
\hline
\end{tabular}

\section{Discussions}

The meaning of this ayah is : forbidding His servant from tyranny and walking, Allah, the Almighty says( And walk not on the earth with conceit and arrogance ) i.e. walking in a boastful manner led by conceit like the arrogant oppressor ; for ( verily, you can neither rend nor penetrate the earth).i.e. you will not split asunder the earth with your walking. ( nor can you attain a stature like the mountain in height)i.e., with your arrogance, vanity, and self-esteem .Rather, the outcome of such acts of arrogance and pride may be the opposite of what one pretends to be; as it is authentically stated in the Sahih that the Messenger of Allah(PBUH) said:" while a man from those who were before you was walking boastfully in his garment, the earth swallowed him and he is still sinking down into it, until the Day of Resurrection. Allah also states about Quran, who, while walking amongst his people wearing finery, Allah caused the earth to swallowed him and his house .It is stated in the Hadith that the Messenger ( (PBUH):"Whoever subdues himself in humbleness to Allah, he will raise him therewith that to a higher degree despite not being of respectful status, he is highly esteemed by people. And whoever acted urgently, Allah will degrade him to a lower level despite having such self-esteem to people; he is mean and hated even more than the dog and pig.

In the example 1 above, the ST phrase في الأرض مرحا was rendered by AbdullahYusuf Ali as " on the earth with insolence" whereas it was rendered by Mohammed Asad as " on the earth with haughty". However, it was rendered by Muhammad Mahmoud Ghali as " walk in the earth merrily". It seems that both AbdullahYusuf Ali's and Mohammed Asad's translation are the most faithful to the Quran Source text (QST), amongst the three translations. Because the two translators, AbdullahYusuf Ali.and Mohammed Asad understood the expression in Arabic language .The two translators used (insolence, haughty, self- concept) lexemes which connoted and implied to (arrogance, vanity, and conceit). As in this example, we found Muhammad Mahmoud Ghali opted to literal translation strategy to render the ST phrase في الأرض مرحا by using explicit lexeme( merrily) which denoted to( happiness and enjoyment) which does not seem to be proper and convey the idiomatic expressions in Arabic language, hence, a loss in connotative meaning seems to have occurred in rendering the ST phrase في الأرض مرحا by Muhammad Mahmoud Ghali whose translation seems divergence from an equivalence that exists in Arabic( i.e., on the earth with insolence, on the earth with haughty"' which seem more appropriate and accurate and faithful translation) than his translation(walk in the earth merrily) 


\section{Examples of Reprehensible Moral Traits (greed) in The Holy Quran Translation}

Example 2

The triliteral root $q \bar{a} f b \bar{a} d \bar{a} d$ (ق ب ض) occurs nine times in the Quran, in four derived forms:

- five times as the form I verb qabad (فَبَّنَ)

- $\quad$ once as the noun qabd (قَبَّ)

- $\quad$ twice as the noun qabdat (قَبْْنَ)

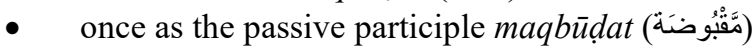

The translations below are brief glosses intended as a guide to meaning. An Arabic word may have a range of meanings depending on context

Retrieved on 30/11/2020 http://corpus.quran.com/qurandictionary.jsp?q=qbD

\begin{tabular}{|c|c|c|c|}
\hline $\begin{array}{c}\text { ST } \\
\text { ( euphemism, greed ) }\end{array}$ & $\begin{array}{c}\text { T1 } \\
\text { AbdullahYusuf Ali, }\end{array}$ & $\begin{array}{c}\text { T2 } \\
\text { Mohammed Asad( }\end{array}$ & $\begin{array}{c}\text { T3 } \\
\text { Muhammad Mahmoud } \\
\text { Ghali. }\end{array}$ \\
\hline 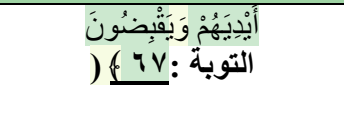 & $\begin{array}{l}\text { Tighten their purse's } \\
\text { strings } \\
\text { (At-Tawbah,67) }\end{array}$ & $\begin{array}{r}\text { And with hold their } \\
\text { hands ( from doing good ) } \\
\text { ( (At-Tawbah,67) }\end{array}$ & $\begin{array}{r}\text { And their keep hands } \\
\text { shut } \\
\text { (At-Tawbah,67) }\end{array}$ \\
\hline
\end{tabular}

\section{Discussions}

The meaning of this (QST) phrase is spending in Allah's cause; such as alms and for helping performing other acts of worship.( Al-jalalayn, vol.1, 2010, p, 584).

was rendered by أَبْدِيَهُم وَيَقْبضضونَن In example 2 above, the (QST) phrase AbdullahYusuf Ali as" tighten their purse's strings" based on the English euphemistic idiomatic expression " tight with t purse string " which means;; miser or greed https://idioms.thefreedictionary.com/tighten+purse+strings retrieved on 30/11/2020).

This English idiomatic expression is considered to be similar equivalent to, hence, it seems that A.Yusuf Ali's translation is faithful أَيْيَنَهُم وَيَفْضِضُونَ the (QST) and may convey the (QST) meaning properly . Mohammed Asad rendered the same meaning into"and withhold their hands( from doing good) where as Ghali rendered it into" and they keep their hands shut" also he used the footnote and literal translation strategy by translating the meaning" they grasp their hands." Which means in context ( they do not give charity)

Finally, the three translators did not pay attention to suitable equivalents in English which will convey the meaning of Quranic greed and in order to enhance the translated Quranic text into English and make it to be similar to the original text the translator may use the following euphemistic expressions:

" (tightwad),'( tight-fisted),(tight),(close fisted ),(close)"

"'( penny-pinching ),(half fisted),(pinch fisted),(close handed)"

These euphemistic expressions are equivalent to the Arabic expression (قبض يده)

\section{CONCLUSION}

This study aimed at identifying the losses in rendering in Qur'anic reprehensible moral traits into English , and how these losses Qur'anic reprehensible moral traits can be reduced, and the causes of the difficulty in conveying some. Qur'anic reprehensible moral traits for this purpose, a qualitative analysis of three ayahs (verses) from the Holy Quran was conducted. The results of the study revealed that loss in Qur'anic reprehensible moral traits occurs because of different factors that can be subsumed under lack of equivalence in the TL that results from the cultural and lexical differences between SL and TL, and $r$ the translation strategies adopted by the translators. The researchers recommend that more research about loss in Qur'anic reprehensible moral traits into English should be conducted and how the loss in Qur'anic reprehensible moral traits into English should to be reduced .

\section{References}

Abdel Haleem, M.A.S. (2011). Euphemisms in the Holy Qur'an: A Case Study of Marital Relations as Depicted in Q-2:222-3. http://www.enppub/ishing.com/doi/abs/103366/jqs.2011

Abdel-Haleem, M (1999). Understanding the Qur'an: Themes and Style. New York: I.B. Tauris and Co. Ltd. Abdullah, A.(2003). Translations of Near Synonyms I the Quran:A Context -based Analysis. Unpublished master's thesis. London: University of London.

Abdelwali, M. (2007). The Loss in the Translation of the Qur'an. Translation Journal, 11 (2), April. Retrieved 10 June, 2010, from http://translationjournal.net/journal/ 40quran.htm.

Abdul-Raof, H. (2001). Qur'ān translation: Discourse, Texture and Exegesis. London: Rutledge.

Abdul-Raof, H. (2003). Conceptual and Textual Chaining in Qur'änic Discourse. Journal of Qur'ānic Studies, 5 (2), $72-94$

Abdelaal, N. M., \& Md Rashid, S. (2015). Semantic loss in the Holy Qur'an translation with special reference to Surah Al-WaqiAAa (Chapter of the Event Inevitable). SAGE Open, 5(4), 1-10. 
Abdelaal, N. M., \& Md Rashid, S. (2016). Grammarrelated semantic losses in the translation of the Holy Quran, with special reference to Surah Al A 'araf (The Heights). SAGE Open, 1(1), 1-11. doi: http://doi.org/10.1177/2158244016661750.

Abū Zayd, Nașr Hāmid. Mafhūm al-nașṣ: Dirāsa fī 'ulūm al-Qur' ān. Cairo: al-Hay'a al-Mișriyya al 'Āmma li-1Kitāb, 1990. Retrieved on 22/11/2019 from https:/www.iasj.net/iasj?func=fulltext\&aId=1938).

Bāqillānī, Abū Bakr al-. Ikfār al-muta'awillīn. Cairo: Ma had al-Makhțūṭāt al-'Arabiyya, 2006. ------. Al-Inșāf fīma yajib al-i 'tiqād wa-lā yajūz al-jahl bihi. Edited by Muḥammad Zāhid alKawtharī. [Cairo]: Mu'assasat al-Khānjī, 1963.

------. Al-Intișār li-l-Qur'ān. Edited by Muhammad 'Ișām al-Quḍāt. 2 vols. Beirut: Dār Ibn Hazm, 2001; edited by 'Umar Hasan al-Qayyām. 2 vols. Beirut: Mu'assasat al-Risāla, 2004.

------. Kitāb al-Bayān 'an al-farq bayna al-mu jizāt wa-l-karamāt wa-l-ḥiyal wa-l-kahāna wa-l-ṣihr wal-nārinjāt. Translated by Richard Joseph McCarthy as Miracle and Magic Kitāb al-Bayān: A Treatise on the Nature of the Apologetic Miracle and Its Differentiation from Charisms, Trickery, Divination, Magic and Spells. Beirut: Librairie Orientale, 1958

Abdul-Raof, H. (2004). The Quran: Limits of translatability. In S. Faiq (Ed.), Cultural encounters in translation from Arabic (pp. 91- 106). Frankfurt Lodge: Multilingual Matters Ltd.

Abdul-Raof, H. (2005). Pragmalinguistic forms in cross-cultural communication: Contributions from Qur'an translation. Intercultural Communication Studies, 14(4), 115-130. Abdul-Raof, H. (2010). Qur'an Translation, discourse, texture and exegesis. Abingdn: Routledge. Ahmed, M. (2008). Approaches to denotative and connotative meanings in the translations of the Holy Quran. Adab Al-Rafidayn, 2(50), 1-30.

Abū-Sayyideh, A. (2001). Synonymy, Collocation and the Translator. Turjuman, 10 (2), 53-71.

Ahmed, M. (2001). Cognitive Bases of Translating Metonymy. Retrievedhttp://www.google.com/search?hl=ar\&lr=\&biw=1259\&bih=551.

Ahmed, Nazik, N. (2008).Translating Religious Text: An Investigation into English Translations of the Thirtieth Part of the Noble Quran. Unpublished PhD Thesis. Omdurman Islamic University.

Akbar, M. (1988). The Meaning of the Qur'an. Lahore: Islamic Publications Ltd.

Al-Azzam, B.H.S. (2005). Certain Terms relating to Islamic Observances: Their Meanings with Reference to Three Translations of the Qur'an and a Translation of Hadith. Boca Raton, Fl: Thesis.com.

Al-Batal, M. (1985). The Cohesive Role of Connectives in a Modern Expository Arabic Text. Unpublished doctoral thesis. Michigan: University of Michigan.

Al-Fakhari,A." On Translation the Noble Quran. Journal of King Saud.Vol.2.3005; p.67.

Al-Haj, Ali Albashir M.(2014).Text Linguistics and Translation.

US: CreateSpace Independent Publishing Platform .

Al-Haj, Ali Albashir M.(2014).Semantics. US : CreateSpace Independent Publishing Platform.

Al-Haj, Ali Albashir M.(2015) A Study of Polysemous Words in Quran Translations. Germany: Berlin, Schaltngsdienst.

Al-Haj, Ali Albashir M.(2015) A Study of Connotative Words in Quran Translations. Germany: Berlin, Schaltngsdienst.

Al-Haj, Ali Albashir M.(2015) Translations Procedures and Strategies and Holy Quran Translation Germany: Berlin, Schaltngsdienst

Ali, A. Y. (1983). The Glorious Quran. The Muslim Studente's Association of - the United States and Canada

Al-Ghazali, M. (2010). Lexical gaps in Arabic -toEnglish translation.Alhaj, Ali Albashir Mohammed, et al. (2019): "Constrains of Rendering Some Selected Qur'anic Verses (Āyahs) into English: A Sociorhetorical Interpretation "International Journal of Linguistics, Literature and Translation 2.5 doi:10.32996/ijllt.2019.2.5.13

Abū-Sayyideh, A. (2001). Synonymy, Collocation and the Translator. Turjuman, 10 (2), 53-71.

Abu Xuder, S.(2010). 'Athar At-Talattuf fi At-Tatawur Al-Mustalahi'. AL-MAJALLAH AL-EARABIYAH LILEULOOM ALINSANIYAH, Kuwait University, Vol.122, pp: 3-39

Ad-Dayah, F. (1996) EELM AD-DILALAH AL-EARABIYAH: ANNADHARIYAH WA AT-TATBIQ, 2nd edition. Damascus: Dar Al-Fikr

Al-Andalusi, A. (1993) TAFSIR AL-BAHR AL-MUHEET, Vol.2. Beirut: Dar Al-Kutub Al-Eilmiyah

Al-Ealawi, Y. (1922) KITAB AT-TIRAZ Al-MUTADAMIN LIASRAR AL-BALAGHAH WA EULOOM HAQA'Q AL-EEJAZ, Vol.1. Cairo: Al-Muqtataf.

Al-Easkari, A. (1952) KITAB AS-SINAEATEIN: AL-KITABAH WA ASH-SHIER. Cairo:Dar Al-Qalam

Al-Farahidi, A (1990) AL-EEIN, vol.3. Baghdad: Dar Al-Hilal

Al-Farra', Y. (1970) MAEANI AL-QUR'AN, Vol. 2. Cairo: Ad-Darul Masriyah Lita'lif wa At-Tarjamah

Al-Jahidh, A. (1990) KITAB AL-BURSAN WA AL-EURJAN WA ALEUMYAN WAL HULAN. Beirut: Dar Al-jeel. 
Al-Jirjani, A. (1908) AL-MUNTAXAB MIM KINAYAT AL-UDABA' WA ISHARAT AL-BULAGHA'. Cairo: As-SaEadah

Al-Qurtubi, M. (2003) AL-JAMIE LI 'AHKAM AL-QUR'AN, vol.2. Riyadh: Ealam Al-Kutub.

Al-'sfahani, A. (1990) MUFRADAT AL-FADH Al-QUR'AN. Damascus: Dar Al-Qalam.

As-Suyouti, J. (1998) AL-MUZHIR FI EULOOM AL-LUGHAH WA AAWAEiIHA. Beirut: Dar Al-Kutub

Al-Eilmiyah. Ath-ThaEalibi, E. (1998). AL- KINAYAH WA AT- TAERID. Cairo: Dar Qibaa

At-Tibi, H. (1977) AT-TIBYAN FI AL-BAYAN. Cairo: Al-Azhar.

Az-Zamaxshari, M. (1979) ASAS AL-BALAGHAH, Vols.1 \& 2. Beirut: Dar Al-Fiker.

Az-Zarkashi, M. (1984) AL-BURHAN FI EULOOM AL-QUR'AN, (3rd edition), vol.2. Cairo: Dar Aturath.

Eumer, A. (1998) EILM AL-DILALAH, (5th edition). Cairo: Ealam Alkitab.

Al-Kharabsheh, A. (2001). Translating Autoantonymy in the Qur'an. Across Languages and Cultures, 9 (1), 17-40.

Al-Suyūṭị, Jalāl al-Dīn (1986). Al-Mazhar fì ulūm al-lughah al- 'Arabiyah. (M. Mawlā, A. al-Jawi and M. Ibrāhīm, Eds.). Baurit: Al-Maktabah al-'Asriyyah.

Al-Zamakhsharī, Abū l-Qāsim (1986). Al-Kashshāf 'an haqū 'iq ghawāmiḍ al-tanz̄̄l. Beirut: Dār al-Ma rifah.

Al- Munjid( Arabic Dictionary),(1999). Beirut: Dar Al- Mashariq.

Catford, J. (1995) Alinguistic Theory of Translation. London. Oxford University Press.

Callon, M (1986) 'Some elements of a sociology of translation: domestication of the scallops and the fishermen of St Brieuc bay', in Law, J (ed) Power, Action and Belief: a new sociology of knowledge?, London: Routledge and Kegan Paul

Creswell, J., \& Miller, D. (2000). Determining validity in qualitative inquiry. Theory into Practice, Noureldin Mohamed Abdelaal 32 Pertanika J. Soc. Sci. \& Hum. 27 (1): 13 - 33 (2019) 39(March 2015), 124-130. doi: http://doi. org/10.1207/s15430421tip3903

Farghal, M. (1995) "Euphemism in Arabic: A Gracian Interpretation" ANTHROPOLOGICAL LINGUISTICS, vol. 37 , No. 3, pp.366-378

Freeman, R 2009, 'What is 'Translation'?', Evidence and Policy, vol. 5, no. 4, pp. 429-447. https://doi.org/10.1332/174426409X478770

Ibn Al-Atheer, N. (1983) AL-MATHAL AS-SA'R FI ADAB AL-KATIB WA ASH-SHEER. Cairo: Nahdat Masir

Ibn Faris, A. (1910) AS-SAHIBI FI FIQH AL-LUGHAH ALEARABIYAH WA MASA'ILIHA WA SUNAN ALEARAB FI KALAMIHA. Beirut: Maktabat Al- Ma'aarif.

Ibn Rashiq, A. (1972) AL-EUMDAH FI MAHASIN ASH-SHIER WA 'ADABIH WA NAQDIH, (4th ed.). Beirut: Dar Aj-Jeel

Khalifa, M. (2005). Translation: Tried and True? Retrieved 20 August, 2010, from http://www.cyberistan.org/islamic/translate.htm.

Khan, M.E.(2008) Approximation of the Meaning of the Holy Quran: A linguistic Analysis. Oxford: B. Blackwell

Laboner(2008).Semantics. London: Continuum.

Leech, G. (1993) Semantics. Harmondsworth: Penguin.

Lewis,R. (2005)Training the Translator. London: The Macmillan Company. Ltd.

Lobner, S. (2002). Understanding semantics. Sonipat, India: Replika Press

Lutz, R. J. MacKenzie, S. B., \& Belch, G. E. (1989). Attitude toward the ad as a mediator of advertising effectiveness: Determinants and consequences. Advances in consumer research, 10(1), 532539Lyons,J.(1998) .Semantics. Vol.1\& 2 London: The Macmillan Company. Ltd.

Sontag, S (2001) Where the Stress Falls. Essays, New York: Farrar, Straus and Giroux

Steiner, G (1998) After Babel. Aspects of language and translation, third edition, Oxford: Oxford UP

Tabrizi, A., \& Mahmud, R. (2013). Coherence analysis issues on English-translated Quran. In Communications, Signal Processing, and their Applications (ICCSPA), (pp. 1-6. Sharjah, United Arab emirates.

Temple, B (2005) 'Nice and tidy: translation and representation', Sociological Research Online 10 (2); .

Tibawi, A. L. (1964/2004). Is the Qur'an Translatable? Early Muslim Opinion. The Muslim World, 52.

Rawson, H. (1981). A Dictionary of Euphemisms and other Double-talk. New York: Crown Publisher 